\title{
Peningkatan Hasil Belajar Mata Pelajaran Al Qur'an Hadits Siswa Melalui Penerapan Metode Talking Chips
}

\author{
Sulis Setyani ${ }^{1}$, Marlina ${ }^{2^{*}}$ \\ ${ }^{12}$ STKIP Nurul Huda OKU Timur \\ *E-mail: marlina@stkipnurulhuda.ac.id
}

\begin{abstract}
Abstrak
Penelitian ini bertujuan untuk memperbaiki proses serta hasil belajar pada mata pelajaran Al Qur'an Hadits melalui penerapan metode Talking Chips. Penelitian dilaksanakan menggunakan desain penelitian tindakan kelas yang dilaksanakan dalam 3 siklus. Prosedur penelitian terdiri atas empat tahapan yaitu perencanaan, pelaksanaan, observasi dan refleksi. Subjek penelitian ini adalah siswa kelas VIII-2 yang berjumlah 27 siswa. Teknik pengumpulan data menggunakan observasi dan tes, sedangkan teknik analisa data menggunakan teknik holberman yaitu reduksi, penyajian dan penarikan kesimpulan.

Kesimpulan penelitian ini pertama; Hasil belajar mata pelajaran Al Qur'an Hadits siswa sebelum penerapan metode Talking Chips di kelas VIII Tahun Pelajaran 2017/2018 adalah sangat rendah dengan skor totol 1240, nilai rata-rata siswa 45,93 dengan persentase ketuntasan sebesar 22,22\%. Kedua; Hasil belajar mata pelajaran Al Qur'an Hadits siswa sebelum penerapan metode Talking Chips di kelas VIII MTs Al Ikhlas Pemetung Basuki Tahun Pelajaran 2017/2018 adalah tinggi dengan skor totol 2250, nilai rata-rata siswa 83,33 dengan persentase ketuntasan sebesar 96,30\% pada siklus 3. Ketiga; Penerapan metode Talking Chips dapat meningkatkan hasil belajar siswa pada mata pelajaran Al Qur'an Hadits di kelas VIII-2 setiap siklusnya sebesar $24,69 \%$. Berdasarkan hasil penelitian maka disarankan agar metode pembelajaran Talking Chips dapat diterapkan pada pembelajaran Al Qur'an Hadits materi pembelajaran lain.
\end{abstract}

Kata kunci: Hasil Belajar, Al Qur'an Hadits, Metode Talking Chips

\section{PENDAHULUAN}

Mata pelajaran Al Qur'an Hadits merupakan sub mata pelajaran Pendidikan Agama Islam yang penting karena mata pelajaran Al Qur'an Hadits berisi materi tentang pemahaman Al Qur'an dan hadits-hadits Nabi SAW sebagai dasar utama ajaran-ajaran Islam. Mata pelajaran AI Qur'an Hadits di Madrasah Tsanawiyah merupakan peningkatan dari Al Qur'an Hadits yang telah dipelajari oleh siswa di tingkat Madrasah Ibtidaiyah. Peningkatan tersebut dilakukan dengan cara mempelajari, memperdalam serta memperkaya kajian Al Qur'an dan Al Hadits terutama menyangkut dasar-dasar keilmuannya sebagai persiapan untuk melanjutkan ke pendidikan yang lebih tinggi, serta memahami dan menerapkan tema-tema tentang manusia dan tanggung jawabnya di muka bumi, demokrasi serta pengembangan ilmu pengetahuan dan teknologi dalam perspektif Al Qur'an dan Al Hadits sebagai persiapan untuk hidup bermasyarakat (Kementerian Agama RI, 2014:3).

Pembelajaran Al Qur'an Hadits pada implementasinya banyak menemukan berbagai kendala dan permasalahan terutama pada aspek metodologi pembelajaran. Hal tersebut sebagaimana terjadi di MTs Al Ikhlas Pemetung Basuki. Berdasarkan hasil pengamatan pendahuluan pada hari Senin tanggal 06 November 2017 diketahui bahwa proses pembelajaran Al Qur'an Hadits di kelas VIII belum maksimal yang ditandai dari sebagian kecil siswa terlibat aktif selama pembelajaran. Siswa pada proses pembelajaran ditempatkan sebagai objek belajar yang bersikap pasif. Kegiatan belajar siswa hanya terbatas pada membaca materi pembelajaran dari buku paket, mendengarkan penjelasan guru tentang materi pembelajaran, tanpa disertai berbagai kegaitan tambahan untuk memperdalam pemahaman terhadap materi pelajaran.

Keadaan pembelajaran Al Qur'an Hadits di kelas VIII MTs Al Ikhlas Pemetung Basuki berimplikasi pada sikap pasif pada diri siswa selama kegiatan pembelajaran. Selama kegiatan 
pembelajaran, siswa hampir tidak pernah bertanya kepada guru dan hanya sesekali menjawab pertanyaan guru. Ketika guru mengajukan pertanyaan-pertanyaan seperti pada tahap apersepsi maupun pada tahap pelaksanaan pembelajaran, hanya ada beberapa siswa yang mau dan dapat menjawab pertanyaan tersebut. Ketika guru selesai menjelaskan materi pembelajaran, guru memberikan kesempatan kepada siswa untuk mengajukan pertanyaan tentang materi pembelajaran yang belum dipahami, tidak ada saru orang siswa pun yang mau mengajukan pertanyaan. Bahkan ketika guru sedang menjelaskan materi pembelajaran, sedikit sekali siswa yang antusias mendengarkan dan memperhatikan penjelasan guru. Ketika guru memberikan penjelasan, sebagian siswa terlihat ada yang mengantuk, berbicara dengan teman sebangku, bahkan ada siswa yang asik menggambar di buku ketika guru menjelaskan.

Hasil observasi pendahuluan juga menunjukkan bahwa pada kegiatan pembelajaran, guru tidak mempergunakan media pembelajaran apapun selain dari buku paket. Kegiatan guru terbatas pada menjelaskan materi pembelajaran secara lisan, kemudian menugaskan siswa untuk mengerjakan soal-soal yang terdapat pada buku paket. Ketika menutup pelajaran, guru hanya memberikan penguatan dengan menugaskan siswa untuk menghafalkan ayat-ayat Al Qur'an maupun hadits Nabi Muhammad SAW sebagaimana pada materi pembelajaran tanpa berupaya memberikan pemahaman lebih terhadap ayat Al Qur'an maupun hadits Nabi Muhammad SAW. Pada pertemuan selanjutnya, guru melakukan absensi dan memanggil siswa satu persatu untuk maju ke depan kelas menghafalkan ayat Al Qur'an maupun hadits Nabi Muhammad SAW. Ketika menghafalkan ayat Al Qur'an maupun hadits Nabi Muhammad SAW, sebagian kecil dari siswa yang dapat menghafal secara baik, sedangkan sebagian besar siswa tidak mampu untuk menghafal.

Mengamati kegiatan pembelajaran Al Qur'an Hadits di kelas VIII MTs AI Ikhlas Pemetung Basuki, peneliti kemudian melakukan wawancara tidak terstruktur kepada siswa yang mampu menghafal ayat Al Qur'an maupun hadits Nabi Muhammad SAW dengan baik. Hasil wawancara tersebut menunjukkan bahwa siswa hanya sekedar hafal ayat Al Qur'an maupun hadits Nabi Muhammad SAW tanpa memiliki pemahaman terhadap ayat Al Qur'an maupun hadits Nabi Muhammad SAW yang telah dihafalkan. Hal tersebut menunjukkan bahwa pembelajaran tidak dapat berjalan dengan baik karena siswa tidak memiliki pemahaman terhadap materi pembelajaran.

Keadaan pembelajaran Al Qur'an Hadits di kelas VIII MTs Al Ikhlas Pemetung Basuki sebagaimana tersebut merupakan implikasi dari kegiatan pembelajaran yang dilaksanakan yaitu dengan cara memberikan catatan, menjelaskan materi pembelajaran dengan teknik ceramah, menugaskan siswa menghafal ayat Al Qur'an maupun hadits Nabi Muhammad SAW, kemudian memberikan evaluasi. Kegiatan pembelajaran tersebut juga mengkibatkan pemahaman siswa terhadap materi pembelajaran menjadi rendah. Hal tersebut sebagaimana hasil dokumentasi nilai midle semester gazal yang menunjukkan dari 27 siswa kelas VIII-2 hanya terdapat 6 orang siswa atau $22,22 \%$ dapat mencapai ketuntasan, sedangkan 21 siswa atau $77,78 \%$ belum mencapai ketuntasan 70. Hal tersebut berbeda dengan kelas VIII-1 yang menunjukkan dari 31 siswa terdapat 26 siswa atau $83,87 \%$ dapat mencapai ketuntasan.

Permasalahan-permasalahan pada pembelajaran AI Qur'an Hadits di kelas VIII-2 MTs Al Ikhlas Pemetung Basuki kemudian dianalisis secara lebih mendalam untuk mengetahui akar penyebab masalah. Hasil analisis menunjukkan bahwa masalah pembelajaran AI Qur'an Hadits di kelas VIII MTs Al Ikhlas Pemetung Basuki bermula dari sistem pembelajaran yang menempatkan siswa sebagai objek belajar atau menggunakan sistem teacer centered learning. Seluruh aktivitas belajar didominasi oleh guru yang menerapkan metode pembelajaran ceramah konvensional. Praktek pembelajaran dilakukan dengan memberikan catatan kepada siswa, menugaskan siswa merangkum materi pembelajaran dari buku paket, guru menjelaskan materi pembelajaran secara lisan, kemudian pembelajaran diakhiri dengan melakukan evaluasi. Pembelajaran demikian mengakibatkan peran siswa dalam belajar sangat sedikit. Aktivitas belajar siswa terbatas pada melaksanakan seluruh instruksi guru tanpa ada aktivitas untuk memahami materi pembelajaran secara keseluruhan. Rutinitas pembelajaran mengakibatkan siswa menjadi pasif, motivasi belajar rendah sehingga 
berimplikasi pada pencapaian hasil belajar yang rendah pula.

Kondisi pembelajaran dan hasil belajar Al Qur'an Hadits siswa kelas VIII-2 MTs Al Ikhlas Pemetung Basuki sebagaimana tersebut menunjukkan ada permasalahan dalam kegiatan pembelajaran yaitu aktivitas belajar siswa yang rendah sehingga berimplikasi pada pencapaian hasil belajar yang rendah pula. Oleh karena itu, peneliti bermaksud mengadakan suatu penelitian berbentuk tindakan kelas dengan menerapkan metode pembelajaran yang menyenangkan dan berbasis aktivitas belajar siswa yaitu metode Talking Chips. Berkaitan metode Talking Chips Suprijono (2014:148) menjelaskan bahwa "Talking berarti berbicara, sedangkan Chips yang berarti kartu. Jadi arti Talking Chips adalah kartu untuk berbicara". Maksud pengertian etimologis tersebut adalah Talking Chips merupakan metode pembelajaran yang dilaksanakan menggunakan media kartu layaknya orang bermain kartu. Kartu dianggap sebagai tiket, sehingga ketika akan berbicara untuk mengemukakan pendapat, siswa harus menjatuhkan kartunya terlebih dahulu.

Metode Talking Chips merupakan metode pembelajaran berbasis edutainment atau pembelajaran yang menyenangkan melalui teknik permainan yaitu permainan kartu atau kancing maupun media lain yang dapat digunakan sebagai tanda pada permainan. Metode Talking Chips adalah pembelajaran yang dilakukan menggunakan kartu yang berfungsi untuk menandai apabila siswa telah berpendapat maupun menjawab pertanyaan. Metode Talking Chips merupakan metode pembelajaran yang dilakukan menggunakan media kartu yang dibagikan kepada seluruh siswa sebagai tiket untuk dapat berbicara dalam suatu forum diskusi dan dijadikan sebagai indikator aktivitas belajar siswa.

Penjelasan metode Talking Chips sebagaimana tersebut menunjukkan bahwa metode Talking Chips dilaksanakan dengan menekankan pada aktivitas belajar siswa sehingga Talking Chips akan efektif diterapkan pada pembelajaran AI Qur'an Hadits. Atas dasar hal tersebut, metode Talking Chips ditawarkan untuk diterapkan pada pembelajaran Al Qur'an Hadits di kelas VIII MTs Al Ikhlas Pemetung Basuki. Implementasi metode Talking Chips pada pembelajaran Al Qur'an Hadits di kelas VIII MTs Al Ikhlas Pemetung Basuki dilaksanakan dengan cara memberikan pengetahuan kepada siswa dengan menuntut siswa dapat berperan aktif membangun pengetahuan pada memorinya. Pada pembelajaran menggunakan metode Talking Chips guru memberikan kemudahan siswa untuk membangun sendiri pengetahuannya dengan memberi kesempatan kepada siswa untuk menemukan atau menerapkan ide-ide dan berupaya menjadikan siswa secara sadar menggunakan strategi sendiri untuk belajar.

Alasan penggunaan metode Talking Chips adalah metode Talking Chips merupakan bentuk dari Cooperative Learning yang dapat mengaktifkan siswa dalam belajar. Selain itu, metode Talking Chips menuntut siswa untuk memahami materi terlebih dahulu sebelum kegiatan pembelajaran, sehingga siswa lebih termotivasi untuk belajar di luar jam pelajaran. Metode Talking Chips banyak memberikan tantangan kepada siswa untuk memahami materi serta terdapat berbagai sanksi apabila siswa tidak memahami materi. Penerapan metode Talking Chips diharapkan dapat meningkatkan motivasi belajar siswa dan meningkatkan aktivitas belajar siswa sehingga siswa akan lebih memahami materi pembelajaran dan memperoleh hasil belajar yang memuaskan. Penerapan metode Talking Chips diharapkan dapat menjadikan suasana pembelajaran yang menyenangkan bagi siswa sehingga motivasi belajar siswa dapat terjaga.

Hasil belajar pada hakikatnya adalah perubahan tingkah laku sebagai hasil belajar dalam pengertian yang lebih luas mencakup bidang kognitif, afektif, dan psikomotorik. Pendapat tersebut sebagaimana dikemukakan Dimyati dan Mudjiono (2009:4) yang menyatakan, "Hasil belajar merupakan hasil dari suatu interaksi tindak belajar dan tindak mengajar. Dari sisi guru, tindak mengajar diakhiri dengan proses evaluasi hasil belajar. Dari sisi siswa, hasil belajar merupakan berakhirnya pengajaran dari puncak proses belajar".

Purwanto (2011:46) menjelaskan bahwa "Hasil belajar merupakan perubahan perilaku siswa akibat belajar. Perubahan perilaku disebabkan karena penguasaan atas sejumlah bahan yang diberikan dalam proses pembelajaran". Hasil belajar dapat berupa perubahan dalam aspek kognitif, 
afektif dan psikomotorik yang diketahui melalui tes atau evaluasi dan diwujudkan dalam bentuk skor maupun nilai berbentuk angka atau huruf. Hal tersebut sebagaimana penjelasan Sudjana (2013:3) bahwa, "Hasil belajar siswa sebagai perubahan tingkah laku sebagai hasil belajar dalam pengertian yang lebih luas mencakup bidang kognitif, afektif, dan psikomotorik".

Pendapat hampir sama dikemukakan Uno (2009:17) yang mengatakan, "Hasil belajar adalah pernyataan yang menunjukkan tentang apa yang mungkin dikerjakan siswa sebagai hasil dari kegiatan belajarnya". Hasil belajar merupakan pengalaman-pengalaman belajar yang diperoleh siswa dalam bentuk kemampuan-kemampuan tertentu. Hasil belajar secara umum, bahwa hasil belajar merupakan salah satu bukti yang menunjukkan kemampuan atau keberhasilan seseorang yang melakukan proses belajar sesuai dengan bobot atau nilai yang diperolehnya.

Berdasarkan penjelasan tentang metode pembelajaran Talking Chips, peneliti bermaksud mengadakan suatu penelitian berbentuk tindakan kelas untuk meningkatkan hasil belajar mata pelajaran Al Qur'an Hadits siswa kelas VIII MTs Al Ikhlas Pemetung Basuki melalui penerapan metode Talking Chips. Oleh karena itu, pada penelitian ini dirumuskan judul "Peningkatan Hasil Belajar Mata Pelajaran Al Qur'an Hadits Siswa Melalui Penerapan Metode Talking Chips di Kelas VIII MTs AI Ikhlas Pemetung Basuki Tahun Pelajaran 2017/2018".

\section{METODE/EKSPERIMEN}

Penelitian ini merupakan bentuk penelitian tindakan kelas atau disebut dengan classroom in action research. Hasan (dalam Sangadji, 2010:110) menjelaskan, "Penelitian tindakan merupakan upaya mengujicobakan ide-ide ke dalam praktik untuk memperbaiki atau mengubah sesuatu agar memperoleh dampak nyata situasi". Upaya tindakan untuk perbaikan dimaksudkan sebagai pencarian jawab atas permasalahan yang dialami guru dalam melaksanakan tugasnya sehari-hari. Jadi masalah-masalah yang diungkap dan dicarikan jalan keluar dalam penelitian adalah masalah yang benar-benar ada dan dialami oleh guru.

Penelitian tindakan kelas memiliki berbagai desain yang salah satunya dan akan digunakan pada penelitian ini adalah desain penelitian Stephen Kemmis. Model desain penelitian tindakan Stephen Kemmis digunakan model refleksi diri (self-reflective) berbentuk spiral, yang setiap siklusnya terdiri atas perencanaan, tindakan, observasi, dan refleksi sebagaimana dijelaskan Suyanto (2011:16) sebagai berikut:

Model PTK yang dikemukakan oleh Kemmis dan Mc Taggart terdiri atas empat komponen, keempat komponen tersebut, meliputi (1) perencanaan, (2) aksi atau tindakan, (3) observasi, dan (4) refleksi. Sesudah suatu siklus selesai di implementasikan, sesudah refleksi, kemudian diikuti dengan perencanaan ulang yang dilaksanakan dalam bentuk siklus tersendiri.

Penjelasan sebagaimana tersebut menunjukkan bahwa penelitian tindakan dapat dipandang sebagai suatu siklus spiral dari penyusunan perencanaan, pelaksanaan tindakan, pengamatan atau observasi, dan refleksi yang selanjutnya mungkin diikuti dengan siklus spiral lanjutan.

Objek penelitian ini adalah proses pembelajaran Al Qur'an Hadits melalui penerapan metode pembelajaran Talking Chips di kelas VIII MTs Al Ikhlas Pemetung Basuki Kecamatan Buay Pemuka Peliung Kabupaten OKU Timur. Pembelajaran dilaksanakan melalui penelitian tindakan dalam siklussiklus berkelanjutan melalui empat tahapan yaitu perencanaan, pelaksanaan, observasi dan refleksi. Subjek dari penelitian ini adalah siswa kelas VIII-2 MTs Al Ikhlas Pemetung Basuki Kecamatan Buay Pemuka Peliung Kabupaten OKU Timur yang berjumlah 27 siswa dengan perincian 12 siswa laki-laki dan 15 siswa perempuan. Penelitian dilaksanakan berdasarkan berbagai data yang dikumpulkan. Oleh karena itu, pada proses penelitian diperlukan berbagai teknik pengumpulan data. Teknik pengumpulan data yang digunakan pada penelitian ini adalah teknik tes dan observasi. Model analisis kualitatif Penelitian Tindakan Kelas ini adalah analisis data adalah model Hubberman meliputi reduksi data, sajian deskriptif dengan alur sajian sistematis, penyimpulan dari hasil penyajian berupa 
dampak Penelitian Tindakan Kelas dan efektivitasnya

\section{HASIL DAN PEMBAHASAN}

Masalah diangkat dalam penelitian ini adalah hasil belajar mata pelajaran Al Qur'an Hadits siswa yang rendah. Setelah masalah penelitian diketahui, dilakukan analisis penyebab masalah dan diketahui bahwa masalah muncul karena pembelajaran Al Qur'an Hadits hanya dilaksanakan secara verbalis. Selain itu, masalah muncul akibat waktu bagi siswa berlatih menganalisis dan merumuskan permasalahan sesuai materi pembelajaran masih kurang sehingga pengetahuan siswa hanya bersifat teoretis. Oleh karena itu, tindakan akan dilakukan dengan metode Talking Chips. Secara keseluruhan hasil dari tindakan dapat dideskripsikan sebagai berikut:

\section{Penerapan Metode Talking Chips pada pembelajaran Al Qur'an Hadits di kelas VIII-2 MTs Al Ikhlas Pemetung Basuki}

Metode Talking Chips diterapkan pada proses pembelajaran siklus mulai siklus 1 sampai siklus 3. Masing-masing siklus dilakukan satu kali pertemuan dengan alokasi waktu $2 \times 40$ menit. Rangkaian kegiatan pembelajaran untuk menerapkan metode Talking Chips dilaksanakan berdasarkan langkah-langkah kegiatan pembelajaran pada rencana kegiatan pembelajaran menggunakan metode Talking Chips. Penerapan metode Talking Chips pada tindakan siklus 1 dilakukan berdasarkan langkah-langkah pembelajaran metode Talking Chips. Pembelajaran dilakukan pada materi pembelajaran hadits tentang keseimbangan hidup di dunia dan akhirat. Kegiatan pembelajaran dilakukan satu kali pertemuan dengan alokasi waktu 2 x 40 menit pada materi hadits tentang keseimbangan hidup di dunia dan akhirat. Secara terperinci langkah-langkah penerapan metode Talking Chips pada pembelajaran Al Qur'an Hadits di kelas VIII-2 MTs Al Ikhlas Pemetung Basuki dapat dilihat pada lampiran 2 rencana pelaksanaan pembelajaran siklus 1.

Penerapan metode Talking Chips pada pertemuan pertama yaitu pada siklus 1 kurang berjalan maksimal. Hal tersebut karena siswa terbiasa menggunakan metode konvensional yang berpusat pada guru, sehingga siswa tampak bingung dalam melaksanakan semua instruksi guru sesuai langkah-langkah penerapan metode Talking Chips. Pada pertemuan kedua, guru menjelaskan secara praktis langkah-langkah penerapan metode Talking Chips. Guru memberikan kesempatan kepada siswa untuk menanyakan langkah kegiatan pembelajaran yang belum dipahami. Pelaksanaan pembelajaran melalui penerapan metode Talking Chips pada pertemuan kedua telah berjalan maksimal, meskipun masih terdapat siswa yang kurang memahami langkah kerja metode Talking Chips.

Pelaksanaan pembelajaran melalui metode Talking Chips dapat berjalan maksimal sesuai rencana pelaksanaan pembelajaran pada pertemuan ketiga yaitu pada siklus 3 . Penerapan metode Talking Chips menjadikan suasana pembelajaran menjadi tampak menyenangkan. Siswa telah mengetahui dan memahami langkah-langkah pembelajaran menggunakan metode Talking Chips, sehingga seluruh skenario pembelajaran dapat berjalan maksimal sebagaimana akan disajikan pada hasil penelitian berupa hasil tindakan setiap siklus melalui penerapan metode Talking Chips.

Hasil Belajar Mata Pelajaran Al Qur'an Hadits Siswa Setelah Penerapan Metode Talking Chips di Kelas VIII-2 MTs Al Ikhlas Pemetung Basuki

Pada setiap akhir kegiatan pembelajaran siklus dilakukan evaluasi untuk mengetahui hasil belajar mata pelajaran Al Qur'an Hadits siswa. Evaluasi dilaksanakan dengan memberikan soal-soal tertulis berbentuk pilihan ganda sebanyak 10 nomor. Hasil belajar AI Qur'an Hadits siswa setiap siklus berdasarkan hasil tes. Hasil tes pada akhir kegiatan pembelajaran prasiklus diperoleh jumlah nilai 1240 , rata-rata 45,93 dan persentase ketuntasan sebesar $22,22 \%$. Setelah tindakan siklus 1 jumlah skor siswa adalah 1590 dengan nilai rata-rata 58,89. Siswa memperoleh nilai sesuai standar ketuntasan minimal pada siklus 1 adalah 11 siswa atau 40,74\%. Pada siklus 2 skor total hasil tes mata pelajaran Al Qur'an Hadits siswa adalah 1980 dengan nilai rata-rata 73,33. Jumlah siswa mencapai kriteria ketuntasan minimal sebanyak 21 siswa atau $77,78 \%$. Pada siklus 3 terjadi peningkatan hasil belajar AI Qur'an Hadits siswa secara signifikan. Jumlah skor total hasil tes siswa 
adalah 2250 dengan nilai rata-rata 83,33. Jumlah siswa mencapai kriteria ketuntasan minimal pada siklus 3 sebanyak 26 siswa atau 96,30\% dari seluruh jumlah siswa.

Peningkatan Hasil Belajar Mata Pelajaran Al Qur'an Hadits Melalui Metode Talking Chips di Kelas VIII-2 MTs Al Ikhlas Pemetung Basuki

Setelah diadakan penelitian yang terdiri dari tiga siklus dan ditempuh dalam 3 kali pertemuan dengan alokasi waktu 6 jam pelajaran diperoleh hasil yang cukup memuaskan. Penerapan metode Talking Chips secara nyata dapat meningkatkan aktivitas guru dalam pembelajaran, aktivitas belajar siswa serta hasil belajar Al Qur'an Hadits siswa yang ditandai dengan ketuntasan hasil belajar siswa yang mengalami peningkatan. Kesimpulan akhir penelitian ini adalah penerapan metode Talking Chips dapat meningkatkan hasil belajar mata pelajaran Al Qur'an Hadits siswa kelas VIII-2 MTs AI Ikhlas Pemetung Basuki rata-rata $24,69 \%$ setiap siklus.

\section{PENUTUP}

Berdasarkan hasil penelitian dan pembahasan yang telah dipaparkan dapat disimpulkan sebagai berikut. a). Hasil belajar mata pelajaran Al Qur'an Hadits siswa sebelum penerapan metode Talking Chips di kelas VIII MTs Al Ikhlas Pemetung Basuki Tahun Pelajaran 2017/2018 adalah sangat rendah dengan skor total 1240, nilai rata-rata siswa 45,93 dengan persentase ketuntasan sebesar $22,22 \%$. b) Hasil belajar mata pelajaran Al Qur'an Hadits siswa setelah penerapan metode Talking Chips di kelas VIII MTs Al Ikhlas Pemetung Basuki Tahun Pelajaran 2017/2018 adalah tinggi dengan skor totol 2250, nilai rata-rata siswa 83,33 dengan persentase ketuntasan sebesar $96,30 \%$ pada siklus 3. c) Penerapan metode Talking Chips dapat meningkatkan hasil belajar siswa pada mata pelajaran AI Qur'an Hadits di kelas VIII-2 MTs Al Ikhlas Pemetung Basuki Kecamatan Buay Pemuka Peliung setiap siklusnya sebesar $24,69 \%$.

\section{UCAPAN TERIMAKASIH}

Ucapan terimakasih ditujukan kepada STKIP Nurul Huda dan Pengelola Jurnal Al I'tibar yang membantu penerbitan artikel ini.

\section{DAFTAR PUSTAKA}

Dimyati dan Mudjiono. 2009. Belajar dan Pembelajaran. Jakarta:Rineka Cipta.

Kementerian Agama RI. 2014. Buku Guru Al Qur'an Hadis. Jakarta: Kementerian Agama.

Purwanto, M. Ngalim. 2011. Psikologi Pendidikan. Bandung: Remaja Rosdakarya.

Sangadji, Etta Mamang. 2010. Metodologi Penelitian; Pendekatan Praktis dalam Penelitian. Yogyakarta: Andi Offside.

Slavin, Robert E. 2012. Cooperative Learning: Teori, Riset dan Praktik. Bandung: Nusa Media.

Sudjana, Nana. 2013. Penilaian Hasil Belajar. Bandung: Remaja Rosdakarya.

Suprijono, Agus. 2014. Model Pembelajaran Kooperatif. Jakarta: Rineka Cipta.

Suyanto. 2011. Pelaksanaan Penelitian Tindakan Kelas. Jakarta: Rineka Cipta.

Uno, Hamzah B. 2009. Model Pembelajaran: Menciptakan Proses Belajar Mengajar yang Kreatif dan Efektif. Jakarta: Bumi Aksara. 